\title{
The Relationship between University Lecturers' Behaviour and Students' Motivation
}

\author{
Abdul Qawi Noori", Hamdan Said, Faizah Mohamad Nor, Faizah Abd Ghani \\ Faculty of Social Sciences \& Humanities, School of Education, Universiti Teknologi Malaysia (UTM), Malaysia
}

Received June 12, 2020; Revised September 12, 2020; Accepted November 7, 2020

\section{Cite This Paper in the following Citation Styles}

(a): [1] Abdul Qawi Noori, Hamdan Said, Faizah Mohamad Nor, Faizah Abd Ghani, "The Relationship between University Lecturers' Behaviour and Students' Motivation, "Universal Journal of Educational Research, Vol. 8, No. 11C, pp. 15 - 22, 2020. DOI: 10.13189/ujer.2020.082303.

(b): Noori, A. Q., Said, H., Mohamad Nor, F., \& Abd Ghani, F. (2020). The Relationship between University Lecturers' Behaviour and Students' Motivation. Universal Journal of Educational Research, 8(11C), 15 - 22. DOI: 10.13189/ujer.2020.082303.

Copyright $\mathrm{O} 2020$ by authors, all rights reserved. Authors agree that this article remains permanently open access under the terms of the Creative Commons Attribution License 4.0 International License

\begin{abstract}
Many studies reported that the way in which lecturers behave with the college-going students affects those students' overall development. Unfortunately, most of the studies related to the influence of lecturers' behaviour on students' development were conducted either in developed or developing countries. There were very limited studies focusing on the influence of lecturers' behaviour on students' development, conducted in developing countries, particularly a country which experienced prolonged war and instability. This quantitative study fulfilled this gap by examining the perceptions of lecturers on the relationship between the lecturer's behaviour and student's motivation. A 5-point Likert-scale questionnaire was used for data collection. The questionnaire was delivered to all lecturers in Takhar University, a very small university in Afghanistan. From a total of 180 questionnaires delivered, only 151 completed and usable questionnaires were returned for further analysis. The data were analysed using the SPSS. The analysis of data indicated that regardless of education levels and the country's rate of development and stability, lecturers' perceptions have a significant influence on lecturers' behaviour and students' motivation. The findings also revealed that the different age categories of the lecturers and their behaviours influenced tertiary education students' motivation differently. It can be concluded that higher education administrators must focus their attention on ensuring that the institutions hire lecturers from different age categories and outstanding behaviour to better influence students' motivation.
\end{abstract}

Keywords Lecturer's Behaviour, Student's Motivation, Student's Achievement, Academic Achievement

\section{Introduction}

Different individuals demonstrate different behaviours in a particular situation they are faced with. Positive behaviours can stimulate others to interact and change their low performance, while negative behaviour may cause people to avoid doing things and change the situation (Scheerens, 2016). Similarly, in higher education institutions, lecturers' attitudes and behaviours may influence students' motivation (Misbah et al., 2015). When the lecturers demonstrate positive attitudes, students may become motivated to learn. Similarly, when the lecturers behave aggressively, the students may be demotivated and stop learning (Bhat \& Khandai, 2015).

As a role model, some characteristics of lecturers' behaviour influence their students. These lecturers' characteristics may include personality, character, manner of interaction, teaching methods frequently employed and way of life (Doménech-Betoret \& Gómez-Artiga, 2014). The behaviours of lecturers may positively or negatively affect students' motivation and learning. This behavioural influence has different outcomes on students' motivation depending on their surroundings (Leoanak \& Amalo, 2018).

Behaviour can be demonstrated in different forms 
including professional behaviour, communicational behaviour, and physical behaviour. Professional behaviour is related to the workplace and profession. In higher education context, it focuses on how lecturers conduct their instructions and communicate with their students, colleagues and management (Etuk, Afangideh \& Uya, 2013). Communicational behaviour relates to a psychological concept that influences a person's thinking and feelings through expression. It is the situation in which a person expresses his or her thought or idea by communicating and interacting with others. In higher education context, behavioural communication is the way lecturers interconnect and communicate with their stakeholders (Ampadu, 2012).

Physical behaviour refers to the actions and arrangements which a person individually performs in a certain scenario. These actions may include exercising, sleeping and any other interactions which are performed in the workplace. Explicitly, a lecturer's physical behaviour may involve the way of interaction, dressing up, being anxious, considering all students equally, and any other actions (Fuhrmann, 2014).

Finally, a lecturer's interpersonal behaviour refers to a psychological approach which directly influences students' motivation. Lecturers' behaviour in this category may include enthusiasm, reward, personal interest and experience, self-esteem, and way of interaction and involvement in educational programmes (Doménech-Betoret \& Gómez-Artiga, 2014). In this category of behaviour, students may come to class with different levels of motivation. However, lecturers' teaching styles, attitudes and social skills may affect students' learning and motivation. Therefore, lecturers need to behave accordingly with students to improve their learning interests.

Behaviour is affected by the attitudes of the people. Motivation helps students to achieve their goals and improve their learning (Zeynali et al., 2019). There are two types of motivation: intrinsic and extrinsic motivation. Intrinsic motivation comes from the person himself; for example, a student might have the desire to learn something to achieve his or her life goal. Extrinsic motivation comes from what a student sees around himself or herself and that which affects his or her way of learning (Doménech-Betoret \& Gómez-Artiga, 2014). Higher motivation increases satisfaction among the students while lack of motivation has negative consequences. Tygrest (2017) found that teacher's behaviour and teaching style affect students' motivation and way of learning. This indicates that motivation is a driving force for students to try harder. It may also provoke the students to work smarter in achieving their goals. Kuo et al. (2019) noted that motivation increases creativity, knowledge, skills, collaboration and learning.

Many studies have examined lecturers' behaviours and its influence on students' motivation. Rodabaugh (1994), for example, examined lecturer behaviours to create an atmosphere of fairness in classroom teaching. The study explored misbehaviours of lecturers that were related to interactional fairness and procedural fairness. The study revealed that misbehaviours related to interactional fairness and procedural fairness were more damaging than giving excessive work or providing dull and boring lectures to the students. Friedman et al. (2005) examined student perceptions towards the ethics of professors and found that there was no difference between students who took a course in ethics and those who did not, in their perception towards ethical or unethical behaviours of professors. The study, however, found that male and female students have different perceptions with regard to ethical behaviours of professors. Frumkin and Murphy (2007) examined Eastern and Western students' perceptions of lecturers' classroom communication style. They found that lecturers' communication styles have differential effects on their students based on gender and culture. They noted that Eastern and Western students rated the same teachers as having different communication patterns.

Stork and Hartley (2009) found that lecturers' poor behaviours have serious consequences on the student's motivation and academic achievement. Some lecturers may choose easy ways to teach the students and do not involve them enough in the learning. Such attitudes badly affect students' motivation (Ali et al., 2009). Malaimak (2010) indicated that lecturers' behaviours can be improved through trainings and capacity building programmes.

Stork and Hartley (2011) examined the perceptions of Chinese and American students regarding lecturers' classroom behaviours. They revealed that Chinese students are more tolerant than American students towards offensive lecturers' behaviours. For American students, competence and respect towards individuals are behaviours important to them while for Chinese students, fulfilment of the role of lecturers' behaviours are important to them. This study indicated that students bring differing expectations and deep cultural foundations to the classroom.

Nambiar et al. (2011) examined Malaysian students' and lecturers' perceptions of good teaching behaviours. They found that students focused more on the lecturers' organization of lecture and the level of interactivity than other variables. Samian and Md Noor (2012) examined Malaysian university students' comments regarding the standards, quality, preparedness, and personality of the lecturers in addition to other usual rating criteria. They found that students' comments correlated with their overall assessment of lecturers' behavioural teaching performance and the ability to deliver lectures effectively. Rahman (2013) found that lecturers' positive behaviour and teaching style influence students' learning. Lecturers' good habits and attitudes inspire students to follow a proper map of learning and improve their achievement (Fuhrmann, 2014).

Britto (2018) investigated the impacts of nonverbal 
behaviours of professors on multicultural students in the United States. She revealed that all students are impacted by the professors' nonverbal behaviours. Zeynali et al. (2019) found that the Iranian university lecturers' attitudes and behaviours affect students' intrinsic and extrinsic motivation. They commented that lecturers need to pay more attention to their behaviours and attitudes to improve students' achievement.

The aforementioned studies were conducted either in developed or developing countries with stable governments. With the exception of studies by Esmaily et al. (2010) and Sabri (2019), limited studies have been conducted in Afghanistan context that focused directly on lecturers' behaviour. This limitation is understandable as there are serious challenges facing higher education system in Afghanistan resulting from prolonged war and instability of the government (Roof, 2015; Kuek et al., 2014). Despite the progress it has made, Afghanistan lingers as one of the least developed countries in the world (Crane \& Rerras, 2009), with very low enrolment ratios in higher education (Aturupane, 2013). The prolonged war and instability, low level of female participation, and high ethnic polarization, seriously impact the higher education system of Afghanistan (Aturupane, 2013; Barakat, 2002). Traditional teaching employed by Afghanistan lecturers intensified the influence of lecturers' behaviours towards students. Despite the low-quality instruction, Afghanistan lecturers still enjoyed high social status in the society and among students (Esmaeily et al., 2010). Unfortunately, this cultural value oftentimes was abused by the lecturers. Lecturers employed rote learning and lecturer-centred education, thus taking full control of delivering the lessons (Sabri, 2019).

The current study fulfils these gaps by examining the lecturers' perceptions of the influence of their behaviour on students' motivation in an Afghanistan public university.

\section{Methodology}

This study was conducted at Takhar University, a small university located at Toloqan City, northern part of Afghanistan, with a total population of 180 lecturers. Like other universities, this university was closed during Taliban administration and was only re-established in 1995. Each lecturer is expected to teach between 15-20 hours per week. Due to the prolonged war and cultural issues, the quality of Afghanistan higher education is severely affected. After 1995 initiatives were put to reduce disparity among ethnic groups including accepting students and lecturers from different cultural and language groups, such as Tajik, Uzbik, and Pashton.

This study employed a questionnaire adapted from Shah (2009) for data collection. The questionnaire contains three sections: section A for demographic of the respondents, and sections $\mathrm{B}$ and $\mathrm{C}$ with with 5-point Likert-Scale questions related to behaviours and student motivation. The questionnaire was piloted on 25 randomly selected lecturers from other universities in Afghanistan before conducting the actual research. These pilot study participants were not included in the actual study. The questionnaire was modified based on the comments received in the pilot study stage. The reliability index for the items in Parts B and C are $\alpha=0.91$ and $\alpha=0.81$ respectively, and overall questionnaire is $\alpha=.93$, which is a very high reliability value.

\section{Results}

The questionnaire was distributed to all 180 lecturers during several faculty meetings. Despite many calls, only 151 questionnaires were returned, completed and usable for analysis. The data analysis was carried out with the aid of SPSS version 25. Table 1 indicates the demographic of the respondents: gender, highest education level, age range, and length of teaching experience.

Table 1. Demographic Analysis of the Respondents

\begin{tabular}{|c|c|c|c|}
\hline \multicolumn{2}{|c|}{ Demographic Information } & \multirow{2}{*}{$\begin{array}{c}\text { Frequency } \\
136\end{array}$} & \multirow{2}{*}{$\begin{array}{c}\text { Percentage } \\
90 \%\end{array}$} \\
\hline \multirow{3}{*}{ Gender } & Male & & \\
\hline & Female & 15 & $10 \%$ \\
\hline & Total & 151 & $100 \%$ \\
\hline \multirow{4}{*}{ Education } & Bachelor & 28 & $19 \%$ \\
\hline & Master & 120 & $79 \%$ \\
\hline & $\mathrm{PhD}$ & 3 & $2 \%$ \\
\hline & Total & 151 & $100 \%$ \\
\hline \multirow{5}{*}{ Age } & $20-25$ & 10 & $7 \%$ \\
\hline & $26-30$ & 69 & $46 \%$ \\
\hline & $31-35$ & 45 & $30 \%$ \\
\hline & 36 and above & 27 & $18 \%$ \\
\hline & Total & 151 & $100 \%$ \\
\hline \multirow{5}{*}{$\begin{array}{l}\text { Teaching } \\
\text { Experience }\end{array}$} & $0-5$ Years & 73 & $48 \%$ \\
\hline & 6-10 Years & 52 & $34 \%$ \\
\hline & $11-15$ & 11 & $7 \%$ \\
\hline & 16 and above & 15 & $10 \%$ \\
\hline & Total & 151 & $100 \%$ \\
\hline
\end{tabular}

Table 1 shows that male lecturers are the big majority $(90 \%)$ while female lecturers are the minority $(10 \%)$. Nearly $80 \%$ possess a master's degree, $20 \%$ possess a bachelor's degree, while only $2 \%$ have a $\mathrm{PhD}$ degree. A huge majority of participants belong to the category of ' 26 to 35 years old' range and majority have less than 10 years of teaching experience. 
Table 2. Descriptive Statistical Analysis for Lecturers' Behaviour

\begin{tabular}{cc}
\hline \multicolumn{2}{c}{ Behaviour of Lecturers } \\
\hline Category of Behaviour & Mean \\
\hline Professional Behaviour & 4.03 \\
Physical Behaviour & 4.28 \\
Communicational Behaviour & 4.65 \\
\hline Overall Mean & 4.41 \\
\hline
\end{tabular}

Table 2 shows three categories of lecturers' behaviours. The overall mean of lecturers' behaviours is 4.41 which shows that all lecturers have positive attitude. Table 2 also shows that lecturers' communicational behaviour has the highest influence on students as compared to physical and professional behaviours.

Table 3. Motivation of the Students

\begin{tabular}{cc}
\hline Motivation & Mean \\
\hline Student Motivation & 4.55 \\
\hline
\end{tabular}

Table 3 indicates the mean of student motivation from the perspective of the lecturers. The analysis shows that lecturers perceived that students have high motivation to learn.

Table 4 shows the result of Spearman correlational analysis. The analysis indicates that the significance level (Alpha value) is $\mathrm{p}=.0001$ which is less than 0.05 (significance level) for both lecturers' behaviour and students' motivation. This study revealed that the lecturers perceive that their behaviours have a moderate significant correlation with their students' motivation.

\section{Discussion}

This study investigated the relationship between lecturers' behaviour and students' motivation from the perspective of lecturers of a small university in Afghanistan, an underdeveloped country tormented by decades of war and instability of political situations. This prolonged war and government instability influenced the quality of higher education where lecturers have limited opportunities to further their studies and very small number of females admitted to the teaching positions (Baharustani, 2012; Taheryar, 2017). This evidence is clearly shown in Table 1 where this is only a very small fraction of lecturers with terminal degrees.

Lecturers' behaviours are the way the lecturers treat and interact with students, colleagues and anyone in higher educational institutions. Despite the low quality of instruction and diverse minority ethnic group issues, the lecturers have the perceptions that their professional behaviours, including the way they teach their students and treat them, affect the students' motivation to learn. The lecturers believed that when they go to lectures with a happy mood and adequate knowledge of subject matter, the students will be motivated and encouraged to learn. This indicates that despite the low-quality instruction, the lecturers may have changed the commonly rendered culture of teaching and learning approaches to produce knowledgeable and skilful graduates (Zakaria, 2017). This may include trying out a critical way of teaching pedagogy, including trying out one form of service-learning programmes which is evidently practical and useful for technical training colleges in Pakistan to employ (Said et al., 2015; Iqbal et al., 2019). The lecturers also believed that they must get themselves adjusted with the usual situation of the university and try to learn new knowledge and transfer it to their students. This perception shows that the lecturers may have indirectly played the role of academic advisors in dealing with minority ethnic groups of students as suggested by Van et al. (2015). With appropriate knowledge and skills in academic advising the lecturers will be better prepared to deliver their instructions.

Table 4. Inferential Statistical Analysis for Spearman Correlational Test

\begin{tabular}{|c|c|c|c|}
\hline & & Students' Motivation & Lecturers' Behaviour \\
\hline \multirow[t]{3}{*}{ Student's Motivation } & Correlation Coefficient & 1 & $0.568^{* *}$ \\
\hline & Sig. (2-tailed) & . & 0.000 \\
\hline & $\mathrm{N}$ & 151 & 151 \\
\hline \multirow[t]{3}{*}{ Lecturer's Behaviour } & Correlation Coefficient & $.568 * *$ & 1 \\
\hline & Sig. (2-tailed) & 0.0001 & . \\
\hline & $\mathrm{N}$ & 151 & 151 \\
\hline
\end{tabular}


The lecturers also perceived that the knowledge and the behaviour that they demonstrate affect on students' outcome. There is high possibility that the behaviour and knowledge they delivered became the motivators that provoked the students to regard their lecturers as role models. This is especially relevant when the lecturers reported that they make their teaching effective by employing diverse teaching techniques and methods. It is also possible that the lecturers have employed various assessment methods including self-assessment and peer-assessment as ways to enhance learning (Machera, 2017). The lecturers perceived that their effective teaching and positive behaviours inspire students to learn better and improve their performance (Sheerens, 2016). The lecturers' positive behaviours enhanced students' learning and development outcomes as proposed by Van et al. (2016a). Van et al. (2016a) reported that students who are clear regarding the learning and development outcomes of advising valued their education and advising programmes better.

The lecturers perceived that their professional behaviours help students to be motivated. The study showed that the lecturers are of the perception that they rendered advice to students regarding their academic problems, for example by giving valuable life examples and assistance in setting up learning goals. This behaviour of advising students matches with the academic advising standard proposed by Van et al. (2016b), which leads to students being motivated to continue learning. In addition, the lecturers also perceived that they demonstrated the behaviours of honesty, diligence, integrity, respect and good ethics which play a significant role in students' learning motivation. This indicates that lecturers perceived that their professional behaviours impact their students. This finding echoes of Orfan (2020) who stated that positive behaviour improves students' motivation. Thus, it can be concluded that professional behaviour of the lecturers plays an important role in the motivation of the students.

The prolonged war and violence make people behave aggressively. Thus, the lecturers are of the perception that negative behaviour may cause students to stop or reject learning, but in situations where respect and good environment are present, students are eager to learn. This perception coincides with the famous saying in Persian language that says: When the lesson of the teacher is whisper of love, children who regularly skip school will come to school even on Friday. This indicates that lecturers' behaviour affects students' motivation to learn.

As stated at the outset lecturers' physical behaviour is the way lecturers physically interact with students. In this study, the lecturers perceived that their physical behaviours play a very important role in student's motivation and learning outcome. They believed that good physical behaviours of the lecturers make the students feel welcome, important and valued, and in consequence, they will be encouraged and motivated to work harder and improve their performance. The behaviours of the lecturers in less developed countries may be different as compared to developed countries. Nevertheless, the lecturers admitted that their negative behaviours may affect students' motivation negatively. It can be stated here that lecturers in Takhar University take disciplinary actions to instruct the students rather than to punish them. It is also possible the university management have shifted emphasis on entrepreneurship just like other universities in the world by asking lecturers to include entrepreneurship elements in their courses (Said et al., 2015a). With these changes then they are of the perception that their behaviours must be positive towards the students. In conclusion, lecturers' good physical behaviour encourages students to improve their learning outcome.

This study also revealed that the lecturers' communicational behaviour inspires the students to improve their academic achievement. Communicational behaviour of the lecturers is the way they verbally interact with the students and colleagues. It is how lecturers answer students' questions, present their lectures and how patient they are with the students. It is a psychological concept that influences students' way of learning, thinking and feeling. The finding of this study supports the study of Ampadu (2012) who indicated that lecturers' communicational behaviour affects students' thinking and motivation. The lecturers perceived that they listen to their students' questions and guide them with their problems. This kind of actions shows that lecturers have positive communicational behaviours with the students. In addition, lecturers perceived that they maintain students' attention and interest in the classroom through effective communication skills, by employing different motivational techniques to inspire their students and providing opportunities for students to ask questions in the class and improve their learning motivation. As a comparison of the perception of different categories of behaviour, lecturers' communicational behaviour is the most commonly demonstrated behaviours to students as compared to professional and physical behaviours. On average, lecturers' behaviour in Takhar University with regard to the students is positive.

The study also revealed that there is a positive significant correlation between lecturer's behaviour and student's motivation. This finding is in tandem with studies of Abdullah et al. (2015), Hein (2012), Loes et al. (2012), and Uluga and Eryilmaz (2011) which reported that there is high correlation between lecturers' behaviours and students' motivation. Lecturers' positive attitudes and teaching style improve students' outcome and learning motivation. In conclusion, lecturers believed that their positive behaviours have strong influence on students' motivation and way of learning.

The study found no significant difference in the perception of male and female lecturers regarding the 
influence of their behaviour on students' motivation and on education levels. The study, however, revealed that there is a significant difference in the perception of lecturers regarding the influence of their behaviour on students' motivation across different age categories.

\section{Conclusion}

Higher education in Afghanistan has been badly affected by prolonged war and government instability. This prolonged war and government instability have caused developmental problems in the country's high education system particularly its quality. Thus, the current government of Afghanistan needs to pay more attention to the quality of higher education by ensuring that it is comparable with higher education in neighbouring countries and the rest of the world. This can be done if the government can render more autonomy to the university. Additionally, the university leadership must put much of their efforts on the internationalization of higher education (Said et al., 2015a).

This study investigated the perceptions of lecturers regarding the influence of their behaviour on students' motivation in Afghanistan. The study revealed that lecturers are of the perception that their behaviours have a strong effect on the students' motivation. Motivation helps students to engage in learning and improve their achievement. For this reason, in high-quality educational system, much attention must be paid to students' motivation and learning outcomes.

Future researchers may find this study significant since there were limited studies exploring the relationship between lecturers' behaviour and students' motivation in higher education in Afghanistan and the rest of the world. This study adds value to the Afghanistan context, since most studies were conducted either in developed countries or developing countries. Higher education administrators, lecturers and educators might find it useful to study the importance of lecturers' behaviours.

Higher education leaders should pay more attention to the improvement of lecturers' behaviours so that the students are engaged and motivated to learn. This study is important as it addressed categories of lecturers' behaviours namely professional, physical and communicational behaviours. The study revealed that students in higher education institutions are highly affected by the behaviours of their lecturers.

The finding of the study shows that lecturers' behaviours play an important role in improving students' motivation and academic achievement in Afghanistan universities. It is generalized that a lecturer's positive behaviour motivates the students to engage in the learning and improve their performance. In conclusion, some lecturers are regarded as role models for some students in higher education institution because of their positive behaviours.

\section{Acknowledgement}

This study was assisted by the management of Takhar University, Afghanistan.

\section{REFERENCES}

[1] Abdullah, M. C., Teoh, H. C., Roslan, S., \& Uli, J. (2015). Student engagement: Concepts, development and application in Malaysian universities. Journal of Educational and Social Research, 5(2), 5-15.

[2] Ahmad, I., Said, H., \& Mohamad Nor, F. (2019). Exploring outcomes of service-learning participation: Evidence from Pakistan. Malaysian Journal of Learning and Instruction, 16(2), 125-154.

[3] Ali, A., Tariq, R. H., \& Topping, J. (2009). Students' perception of university teaching behaviours. Teaching in Higher Education, 14(6), 631-647.

[4] Ampadu, E. (2012). Students' perceptions of their teachers'teaching of mathematics: The case of Ghana. International Online Journal of Educational Sciences, 4(2), $351-358$

[5] Aturupane, H. (2013). Higher education in Afghanistan: An emerging mountain scape. Washington, DC: The World Bank.

[6] Baharustani, R. (2012). Comprehensive study of higher education in Afghanistan. Research and Planning Department.

[7] Barakat, S. (2002). Setting the scene for Afghanistan's reconstruction: The challenges and critical dilemmas. Third World Quarterly, 23(5), 801-816. doi: 10.2307/3993389

[8] Bhat, Y. I., \& Khandai, H. (2015). Academic achievements and study habits of college students of District Pulwama. Journal of Education and Practice, 6(31), 1-6.

[9] Britto, J. (2018). The study of multicultural students' perception of professors' nonverbal behaviour in the classroom. Master of Arts Thesis. University of Rhode Island, USA

[10] Crane, M., \& Rerras, T. (2009). It becomes a river: Afghanistan at a crossroads. World Policy Journal, 26(1), 95-104.

[11] Doménech-Betoret, F., \& Gómez-Artiga, A. (2014). The relationship among students' and teachers' thinking styles, psychological needs and motivation. Learning and Individual Differences, 2(9), 89-97.

[12] Esmaeily, A., Pahwa, A., Thompson, J., \& Watts, D. (2010). AC 2010-2354: Challenges and opportunities in strengthening higher education in Afghanistan. Kansas: American Society for Engineering Education.

[13] Etuk, E. N., Afangideh, M. E., \& Uya, O. A. (2013). Students' perception of teachers' characteristics and their attitude towards Mathematics in Oron Education Zone, Nigeria. International Education Studies, 6(2), 197-204. 
[14] Friedman, H. H., Fogel, J., \& Friedman, L. W. (2005). Student perceptions of the ethics of professors. Electronic Journal of Business Ethics and Organization Studies, 10(2), 10-15.

[15] Frumkin, L. A., \& Murphy, A. (2007). Student perceptions of lecturer classroom communication style. European Journal of Social Sciences, 5(3), 45-60.

[16] Fuhrmann, B. G. (2014). Students' perception of teaching behaviour and its effect on evaluation. International Journal for Cross-Disciplinary Subjects in Education, 5(1), $1557-1563$

[17] Hein, V. (2012). The effect of teacher behaviour on students motivation and learning outcomes: A review. Acta Kinesiologiae Universitatis Tartuensis, 18, 9-19.

[18] Kuek, J. C., Velasquez, R. J., Castellanos, J., Velasquez, D. R., \& Nogales, E. (2014). Hunger for an education: A research essay on the case of South Sudan and the voices of its people. FIRE: Forum for International Research in Education, 1(2), 22-31.

[19] Kuo, H. C., Tseng, Y. C., \& Yang, Y. T. C. (2019). Promoting college student's learning motivation and creativity through a STEM interdisciplinary PBL human-computer interaction system design and development course. Thinking Skills and Creativity, 31(18), $1-10$.

[20] Leoanak, S. P. P., \& Amalo, B. K. (2018). Teacher's behaviour towards students' motivation practice. Global Conference on Teaching, Assessment, and Learning in Education (GCTALE 2017), 42, Article No. 00078.

[21] Loes, C. N., Saichaie, K., Padgett, R., \& Pascarella, E. (2012). The effects of teacher behaviours on students' inclination to inquire and lifelong learning. International Journal for the Scholarship of Teaching and Learning, 6(2), $1-20$.

[22] Machera, R. P. (2017). Teaching intervention strategies that enhance learning in higher education. Universal Journal of Educational Research, 5(5), 733 - $743 . \quad$ Doi: 10.13189/ujer.2017.050505.

[23] Malaimak, M. N. (2010). Students' perception towards English teacher's interpersonal communication skill at SMP Negeri 3 Kupang. Journal of Education and Learning, 10(4), 382-389.

[24] Mehdipour, Y., \& Balaramulu, D. (2013). The influence of teacher's behaviour on the academic achievement International Journal of Advancements in Research \& Technology, 2(5), 217-224.

[25] Misbah, Z., Gulikers, J., Maulana, R. \& Mulder, M., (2015). Teacher interpersonal behaviour and student motivation in competence-based vocational education: Evidence from Indonesia. Teaching and Teacher Education. 50, 79-89.

[26] Mustafa, J., Mohammad Zayed, N., \& Islam, S. (2018). Student's perception towards their lecturer's behaviour: A case study on the undergraduate students of Daffodil International. International Journal of Development and Research, 8(10), 23387-23392

[27] Nambiar, R. M. K., Gill, S. K., Ibrahim, N. M., \& Tan, K. H. (2011). Students and lecturers' perceptions of what constitutes effective teaching behaviour in a university. The
Journal of Asia TEFL, 8(3), 29-53.

[28] Orfan, S.N. (2020). Afghan undergraduate students' attitudes towards learning English. Cogent Arts and Humanities, 7(1), 2331-1983.

[29] Rabae'i, S. (2014). Influence of personality on academic achievement and performance of teaching practices students in TVET. Developing Country Studies, 4(16), 60-65.

[30] Rahman, M. M. (2013). Quality higher education and students' perception: A study on private universities of Bangladesh. Global Disclosure of Economics and Business, 2(1), 9-19.

[31] Rodabaugh, R. C. (1994). College students' perceptions of unfairness in the classroom. To Improve the Academy, 319, 269-282.

[32] Roof, D. J. (2015). Day-by-day: Higher education in Afghanistan. FIRE - Forum for International Research in Education, 1(3), 64-80.

[33] Sabri, A. (2019). Afghan students' academic experiences and cultural adjustment in the United States. Capstone Collection. 3191.

[34] Said, H., Ahmad, I., Hassan, Z., \& Awang, Z. (2015). Service-learning as critical pedagogy: Implications for student community awareness and citizenship development. Mediterranean Journal of Social Sciences, 6(2), 471-478.

[35] Said, H., Ahmad, I., Mustaffa, M. S., \& Ghani, F. A. (2015a). Role of campus leadership in managing change and challenges of internationalization of higher education. Mediterranean Journal of Social Sciences, 6(4S1), 82-88.

[36] Said, H., Ahmad, I., Yusof, M.A. M., \& Jusoh, A. (2015b). Assessing the role of higher education in developing social entrepreneurship in Malaysia: A review of literature. Mediterranean Journal of Social Sciences, 6(2), 583-587.

[37] Samian, Y., \& Md Noor, N. (2012). Students' perception on good lecturer based on lecturer performance assessment. Procedia - Social and Behavioural Sciences, 56(2012), 783 $-790$.

[38] Scheerens, J. (2016). Theories on educational effectiveness and ineffectiveness. In J. Scheerens (eds.), Educational effectiveness and ineffectiveness: A critical review of the knowledge base (pp. 259-289). Dordrecht: Springer.

[39] Shah, S. S. A. (2009). Impact of teachers behaviour on the academic achievement of university students. Journal of College Teaching \& Learning, 6(1), 69-74.

[40] Stork, E. \& Hartley, N.T. (2009). Classroom incivilities: Students' perceptions about professors' behaviours. The Journal of Contemporary Issues in Education Research, $2(4), 13-24$

[41] Stork, E., \& Hartley, N. T. (2011). A comparison of Chinese and American college students' perceptions of professors' behaviours. Journal of International Education Research, $7(4), 1-10$.

[42] Taheryar, M. (2017). Perceptions of quality in higher education in Afghanistan: A case study of Shaheed Rabbani Education University. Master's Capstone Project, University of Massachusetts Amherst, USA.

[43] Tygret, J. A. (2017). The influence of student teachers on 
student achievement: A case study of teacher perspectives. Teaching and Teacher Education, 66, 117-126.

[44] Uluga, M., Ozdenb, M. S., \& Eryilmaz, A. (2011). The effects of teachers' attitudes on students' personality and performance. Procedia - Social and Behavioural Sciences, $30,738-742$

[45] Van, N. T., Said, H., Awang, Z., \& Khan, A. (2016a). Student perspective on learning and development outcomes of academic advising at Universiti Teknologi Malaysia. Man in India, 96(1-2), 675-688.

[46] Van, N. T., Said, H., \& Khan, A. (2016b). Component of an academic advising program standard for Malaysian public universities. Man in India, 96(6), 1691-1702.
[47] Van, N. T., Said, H., Rameli, M. R. M., Karim, N. A., Tajuddin, N., \& Chai, T. T. (2015). Role of academic advising in mitigating the challenges of ethnic minority students at University Teknologi Malaysia. International Education Studies, 8(13), 52-59.

[48] Zakaria, S. (2017). The ever-challenging environment of producing knowledgeable and skilful graduates: Changing the culture of higher education of institutions in teaching and learning approaches. Universal Journal of Educational Research, 5(5), 705-709.

[49] Zeynali, S., Pishghadam, R., \& Fatemi, A. H. (2019). Identifying the motivational and demotivational factors influencing students' academic achievements in language education. Learning and Motivation, 8(2019), 1-12. 